\title{
Viral mortality of the marine alga Emiliania huxleyi (Haptophyceae) and termination of algal blooms
}

\author{
Gunnar Bratbak $^{1}$, Jorun K. Egge ${ }^{2}$, Mikal Heldal ${ }^{1}$ \\ ${ }^{1}$ Department of Microbiology and Plant Physiology, University of Bergen, Jahnebakken 5, N-5020 Bergen, Norway \\ ${ }^{2}$ Department of Fisheries and Marine Biology, University of Bergen, Høyteknologisenteret i Bergen, N-5020 Bergen, Norway
}

\begin{abstract}
The possible roles of viruses in phytoplankton dynamics were investigated in seawater mesocosms with natural assemblages of phytoplankton growing under various nutrient regimes. Blooms of the marine coccolithophorid Emiliania huxleyi (Lohmann) Hay \& Mohler were in some cases succeeded by an increase in the abundance of a morphologically homogeneous population of viruses. The viruses had an hexagonal outline and were about $180 \mathrm{~nm}$ in diameter. Similar viruses were found both intracellularly and associated with apparently lysed cells. Viral lysis could account for 25 to $100 \%$ of the net mortality of $E$. huxleyi when the blooms declined under non-limiting nutrient conditions or when the nitrate concentration was low. Production of viruses was limited when the phosphate concentration was low. During a bloom of E. huxleyi in Norwegian coastal waters in 1990 we found that the concentration of free algal viruses was increasing at the end of the bloom, indicating that viruses of $E$. huxleyi may be important under natural conditions as well. These results suggest that viral mortality of phytoplankton may be an important factor regulating community structure, diversity and biomass production in marine environments.
\end{abstract}

\section{INTRODUCTION}

Virus-like particles (VLP) have occasionally been found in cells from all major algal classes (Dodds 1979, Van Etten et al. 1991). Studies of natural communities indicate that VLP are both widespread and frequently occurring in marine phytoplankton (Manton \& Leadbeater 1974, Pienaar 1976, Mayer \& Taylor 1979, Johnson \& Sieburth 1982, Sieburth et al. 1988, Cottrell \& Suttle 1991, Proctor \& Fuhrman 1991). Moreover, viruses concentrated from seawater can infect and lyse a variety of marine phytoplankton under experimental laboratory conditions (Suttle et al. 1990, 1991).

The marine coccolithophorid Emiliania huxleyi (Lohmann) Hay \& Mohler and related species have a world-wide distribution. Blooms are frequently observed in offshore, coastal and oceanic waters at midlatitudes (45 to $65^{\circ} \mathrm{N}$ ) during spring and summer (Ackleson et al. 1988). Typical maximum concentrations in these areas are about $5 \times 10^{6} \mathrm{cells}^{-1}$ (Holligan et al. 1983, Ackleson et al. 1988). In Norwegian coastal waters and fjords $E$. huxleyi blooms annually in May through July. Cell densities of 2 to $3 \times 10^{7} \mathrm{I}^{-1}$ are typical (Berit R. Heimdal pers. comm.), but values as high as $1.2 \times 10^{8} 1^{-1}$ have been recorded (Berge 1962). The abundance of $E$. huxleyi, its vast capacity to produce coccoliths of calcium carbonate and its emission of dimethylsulphide (DMS) makes it an important species with respect to past and present marine primary production and sediment formation (Berger 1976, Honjo 1976, Westbroek et al. 1989) and to ocean climate and natural acid rain (Charlson et al. 1987). E huxleyi from marine nanoplankton samples have been reported to contain viral particles approximately $200 \mathrm{~nm}$ in diameter (erroneously reported as $22 \mathrm{~nm}$ ) (Manton \& Leadbeater 1974).

Our study was undertaken as a part of a series of mesocosm experiments that were carried out during May through July in 1988 to 1991. The general purpose of these experiments, comprising a total of $33 \mathrm{en}$ - 
closures, was to investigate effects of dissolved nutrient composition on phytoplankton dynamics. The work reported here describes the possible roles of viruses in phytoplankton dynamics.

\section{MATERIALS AND METHODS}

The mesocosm experiments were carried out during May through July in 1988 to 1991 in a bay by the Marine Biological Field Station (Espeland) adjacent to Raunefjorden, $20 \mathrm{~km}$ south of Bergen, western Norway. The enclosures were mounted on floating frames that were moored to a raft in the middle of the bay (for details see Egge \& Aksnes 1992). They were $4 \mathrm{~m}$ deep and $2 \mathrm{~m}$ wide (volume: $11 \mathrm{~m}^{3}$ ), made of $0.15 \mathrm{~mm}$ thick polyethylene $190 \%$ light penetration, PAR) and open to the air. The enclosures were filled with unfiltered natural seawater from $1 \mathrm{~m}$, except for the experiment carried out in 1988 where the water was passed through a $25 \mu \mathrm{m}$ net. The water in the enclosures was renewed continuously with water pumped in from $1 \mathrm{~m}$ depth. In the 1988 experiment this water was filtered as above. Homogeneous water masses within the enclosures were ensured by an airlift system that pumped water from the bottom of the enclosures to the surface at a rate of $401 \mathrm{~min}^{-1}$. The enclosures were enriched with nitrate $\left(\mathrm{NaNO}_{3}\right)$ and phosphate $\left(\mathrm{K}_{2} \mathrm{HPO}_{4}\right)$. The nutrients were administered as concentrated stock solutions after the daily sampling of the enclosures. Initial nutrient loading, daily nutrient supply and dilution rates are given in Table 1.

Phytoplankton were counted live in a FuchsRosenthal hemacytometer or in samples preserved with neutral formaldehyde and concentrated by sedimentation (Utermöhl 1931).
Free VLP were counted in samples preserved with acid Lugol's solution. The low pH of the Lugol's solution caused the dissolution of the coccoliths of Emiliania huxleyi making it possible to count the VLP (detached coccoliths would otherwise cover the preparations completely). Suspended particles were harvested by centrifugation (200000 $\times g, 1 \mathrm{~h})$, prepared for transmission electron microscopy (TEM) and counted as described earlier (Børsheim et al. 1990, Bratbak et al. 1990). The VLP we related to E. huxleyi were recognized by size and morphology and counted at $20000 \times$ magnification. A total of 10 to 600 VLP in 10 to 40 fields were counted for each sample yielding a counting error between 4 to $30 \%$. VLP preserved with Lugol's solution showed no sign of morphological deterioration, even after 3 yr of storage.

In the experiment conducted in 1991 one nitratedeficient enclosure was sampled every second or third day during the Emiliania huxleyi bloom for thin sectioning of cells. Water samples of $10 \mathrm{l}$ were preserved immediately after sampling with glutaraldehyde $\{0.25 \%$ final concentration). The cells were concentrated by tangential flow filtration (Ultrasette, pore size $0.16 \mu \mathrm{m}$, Filtron Technology Corp. Northborough, MA, USA) to a final volume of $100 \mathrm{ml}$ within $6 \mathrm{~h}$ of sampling and then fixed with $1 \%$ glutaraldehyde. The cells were further concentrated by sedimentation, postfixed for $1 \mathrm{~h}$ with $1 \% \mathrm{OsO}_{4}$ in $\mathrm{Na}$-cacodylate buffer ( $\mathrm{pH} 7.3$ ), dehydrated in a graded ethanol series, embedded in Spurr's medium and sectioned. The thin sections were poststained with uranyl acetate $(2 \%)$ and Reynolds $\mathrm{Pb}$-citrate and viewed in a Jeol $100 \mathrm{CX}$ transmission electron microscope at $80 \mathrm{kV}$ accelerating voltage. Between 100 and 300 cell sections were examined for intracellular VLP in each sample.

Unfiltered samples for nutrient analysis were preserved by adding chloroform and analysed within a

Table 1 Experimental manipulations of the enclosures

\begin{tabular}{|c|c|c|c|c|c|c|}
\hline \multirow[t]{2}{*}{ Year } & \multirow[t]{2}{*}{$\begin{array}{l}\text { Results } \\
\text { Fig. }\end{array}$} & \multicolumn{2}{|c|}{$\begin{array}{l}\text { Initial nutrient loading } \\
\qquad\left(\text { umol } \mathrm{l}^{-1}\right)\end{array}$} & \multicolumn{2}{|c|}{$\begin{array}{l}\text { Daily nutrient supply } \\
\left.\text { (umol }{ }^{-1}\right)\end{array}$} & \multirow[t]{2}{*}{$\begin{array}{l}\text { Dilution rate } \\
\qquad\left(d^{-1}\right)\end{array}$} \\
\hline & & $N$ & $\mathrm{P}$ & $N$ & $P$ & \\
\hline 1988 & $1 \mathrm{a}, \mathrm{b}$ & 31 & 6.8 & $5.5^{b}$ & $1.5^{b}$ & 0.3 \\
\hline 1989 & $1 \mathrm{c}, \mathrm{d}$ & 5 & 5 & 5 & 5 & 0.2 \\
\hline \multirow[t]{4}{*}{1991} & $3 a, b$ & 12.6 & 1.5 & 1.3 & 0.15 & 0.1 \\
\hline & $3 c, d$ & 14.7 & 1.6 & 1.5 & 0.16 & 0.1 \\
\hline & $4 a, b$ & 12.6 & 0.1 & 1.3 & 0.01 & 0.1 \\
\hline & $4 \mathrm{c}, \mathrm{d}$ & 13.9 & 0.1 & 1.4 & 0.01 & 0.1 \\
\hline \multirow[t]{2}{*}{1990} & $5 a b$ & 15.2 & 2.0 & 1.5 & 0.2 & 0.1 \\
\hline & $5 \mathrm{c}, \mathrm{d}$ & 15.1 & 2.0 & 1.5 & 0.2 & 0.1 \\
\hline \multicolumn{7}{|c|}{$\begin{array}{l}{ }^{\mathrm{N}} \mathrm{N} \text { and } \mathrm{P} \text { in the inflowing water are not included. They generally made up less than } 10 \% \text { of the daily nutrient supply excep } \\
\text { when the } \mathrm{P} \text { concentration was low }\left(0.01 \mu \mathrm{mol} \mathrm{l}^{-1}\right) \text { where } \mathrm{P} \text { in the inflowing water made up a daily nutrient supply of } 0.016 \\
\mu \mathrm{mol} \mathrm{l}^{-1}\end{array}$} \\
\hline
\end{tabular}


Table 2. Summary of results from the mesocosm experiments showing the relationship between nutrient availability when the blooms culminates and change in abundances of Emiliania huxleyi and of large viral-like particles (LVLP)

\begin{tabular}{|c|c|c|c|c|c|}
\hline \multirow[t]{2}{*}{ Year } & \multirow{2}{*}{$\begin{array}{l}\text { Results } \\
\text { Fig. }\end{array}$} & \multicolumn{2}{|c|}{ Relative nutrient concentrations } & \multicolumn{2}{|c|}{ Change in relative abundances } \\
\hline & & N & $\mathrm{P}$ & E. huxleyi & LVLP \\
\hline 1988 & $1 a, b$ & In excess & In excess & Down & Up \\
\hline 1989 & $1 c, d$ & In excess & In excess & Down & $\mathrm{Up}$ \\
\hline \multirow[t]{4}{*}{1991} & $3 a, b$ & Low & In excess & Down & Up \\
\hline & $3 c, d$ & Low & In excess & Down & Up \\
\hline & $4 \mathrm{a}, \mathrm{b}$ & In excess & Low & No change & No change \\
\hline & $4 \mathrm{C}, \mathrm{d}$ & In excess & Low & No change & No change \\
\hline \multirow[t]{2}{*}{1990} & $5 a, b$ & Low & Low & Down & No change \\
\hline & $5 c, d$ & Low & Low & Down & No change \\
\hline
\end{tabular}

few days or at the end of the experiments. Nitrate, phosphate and silicate concentration were determined in a Chemlab autoanalyzer according to Strickland \& Parsons (1972).

\section{RESULTS}

Emiliania huxleyi formed blooms and was the dominant phytoplankter in all of the 11 enclosure experi- ments where nitrate and phosphate were added and where the silicate concentration was $<2 \mu \mathrm{mol} \mathrm{l}^{-1}$ (data on $\mathrm{Si}$ is not shown). E. huxleyi was also present in some of the enclosures where the silicate concentration was $>2 \mu \mathrm{mol}^{-1}$, but diatoms were always dominant in these enclosures (Egge \& Aksnes 1992). Results from 8 enclosures with silicate concentrations $<\left.2 \mu \mathrm{mol}\right|^{-1}$ are reported in detail here to describe the interaction between E. huxleyi and the VLP we associated with this alga (Table 2).

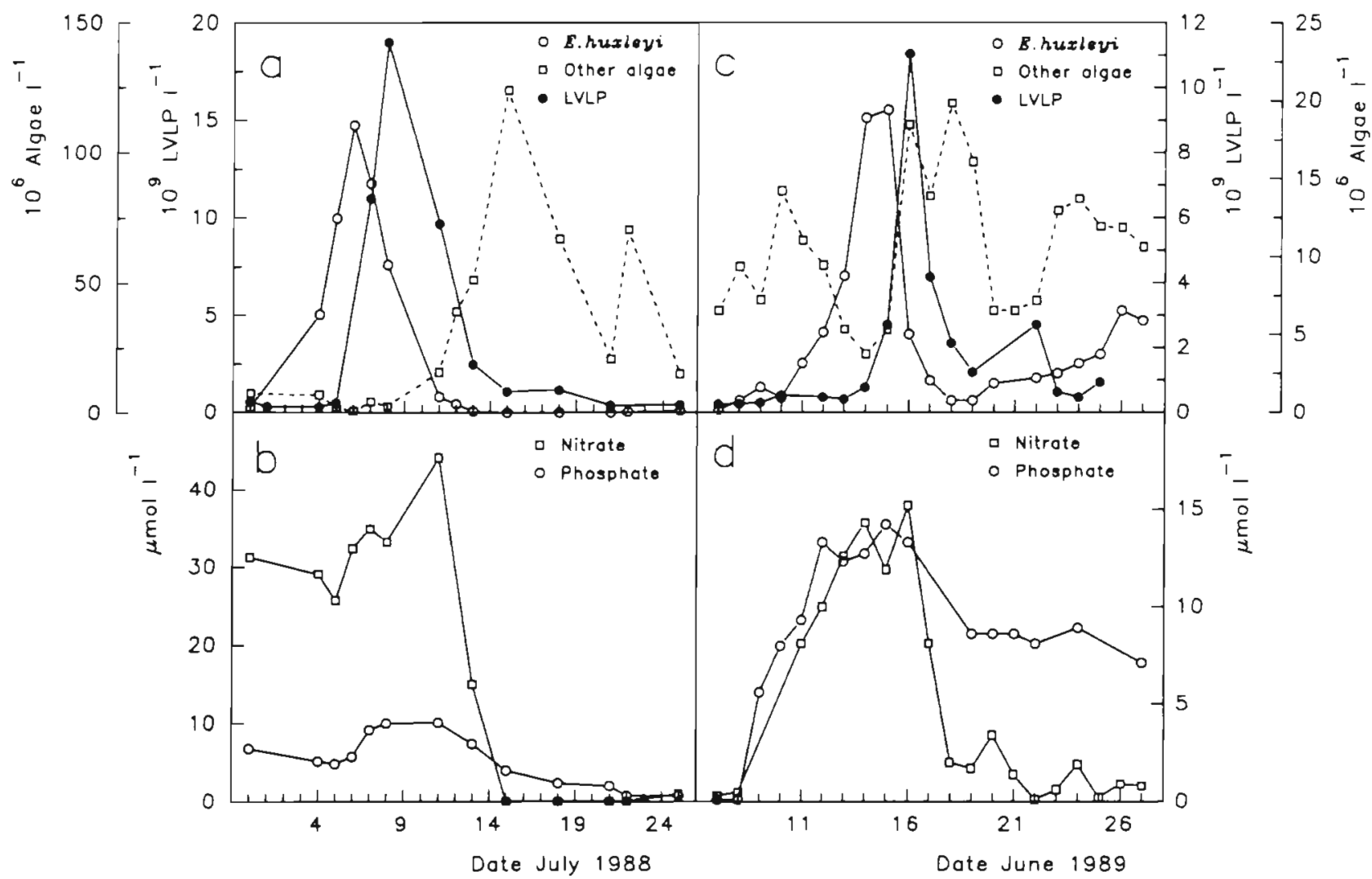

Fig. 1. Emiliania huxleyi. Two mesocosm experiments where both nitrate and phosphate were in excess during the E. huxleyi bloom. ( $a, c)$ Abundance of E. huxleyi, other algae, and large virus-like particles (LVLP). (b, d) Concentration of nitrate and phosphate 


\section{Blooms where phosphate was in excess}

The phytoplankton density in the 1988 experiment was 5 to 6 times higher than the density observed in the 1989 experiment (Fig. 1a, c). In the 1988 experiment Emiliania huxleyi constituted $>99 \%$ of the phytoplankton community when the bloom culminated (Fig. 1a). In the 1989 experiment E. huxleyi was less dominant and comprised only about $80 \%$ of the phytoplankton community when the bloom culminated. In both these experiments the E. huxleyi blooms collapsed while the nutrient concentrations were non-

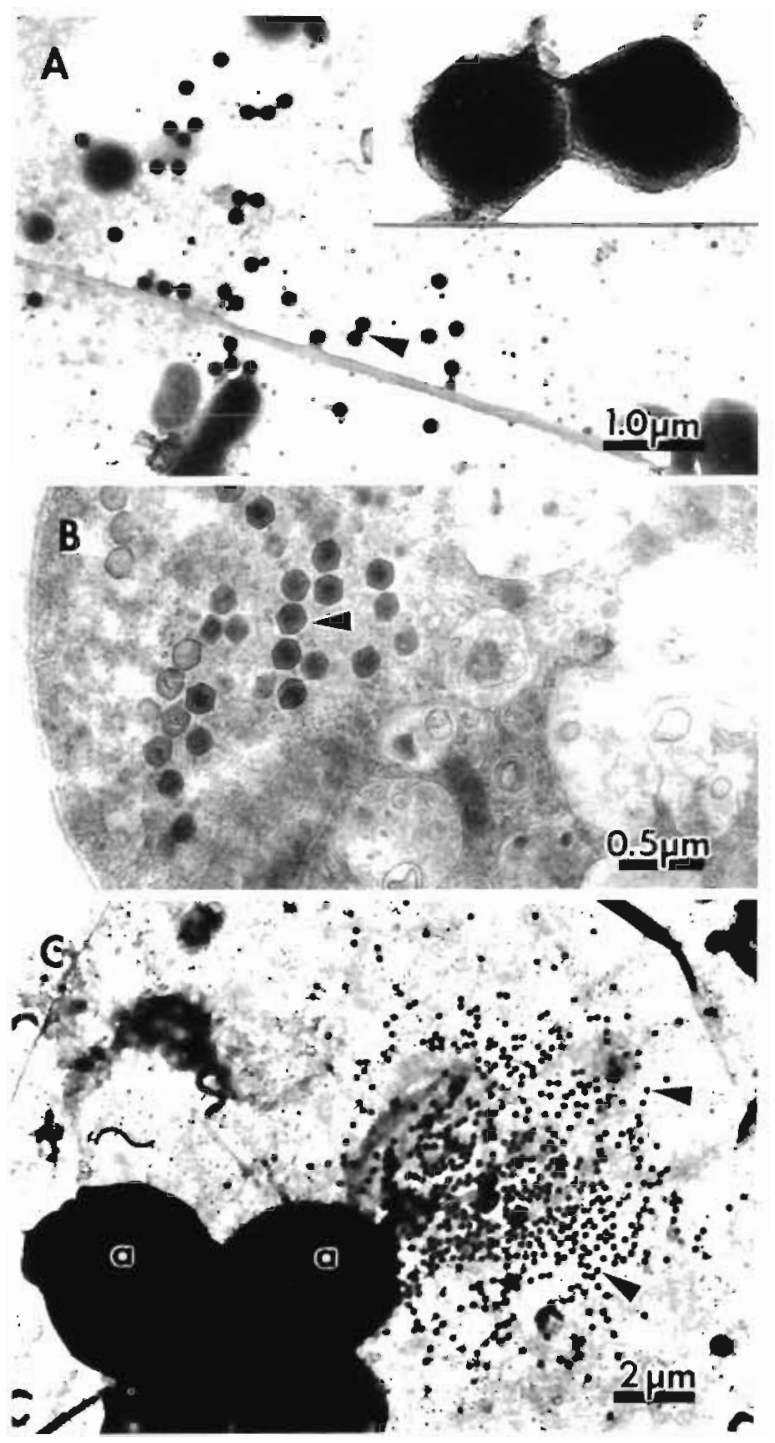

Fig. 2. Emiliania huxleyi. Electron micrographs of large viruslike particles (LVLP) farrowheads) related to the E. huxleyi bloom. (A) The free LVLP enumerated in this study. Note the large number of small $(<60 \mathrm{~nm})$ VLP, most of which probably are bacteriophages. High magnification of LVLP $(90000 \times)$ inserted. (B) Thin section of $E$. huxleyi cells showing intracellular LVLP. (C) E huxleyi cell (a) apparently in the process of releasing LVLP limiting (Table 2, Fig. 1b, d) and was succeeded by a bloom of other algae (Fig, 1a, c). In 1988 this second bloom was dominated by Phaeocystis sp. and small unidentified flagellates, whereas in 1989 it was dominated by the dinoflagellate Katodinium rotundatum (Lohmann) Loeblich III, unidentified cryptophytes and small flagellates.

In both experiments we observed an increase in the abundance of a morphologically homogeneous population of relatively large virus-like particles (LVLP) as the Emiliania huxleyi blooms collapsed (Table 2, Fig. $1 \mathrm{a}, \mathrm{c})$. Similar increases in LVLP were not observed as the blooms of other algae in the enclosures collapsed (Fig. 1 a, c). The LVLP had a hexagonal outline and a diameter of about $180 \mathrm{~nm}$ (Fig. 2A). The abundance of these LVLP culminated after the end of the E. huxleyi blooms and subsequently decreased during the next 3 to $6 \mathrm{~d}$ at a rate between 0.2 and $1.0 \mathrm{~d}^{-1}$ in both experiments. The rate of decrease $(h)$ was calculated as $h=$ $\ln \left(C / C_{0}\right) / \Delta t$ where $C_{0}$ and $C$ are the LVLP abundance at the beginning and at the end of the time interval $\Delta t$. By subtracting the dilution rate (Table 1) we estimate the decay rate of the LVLP to be 0.1 to $0.8 \mathrm{~d}^{-1}$ (mean $\left.0.4 \mathrm{~d}^{-1}\right)$. These rates are minimum estimates being based on net changes in LVLP concentration and assuming the concurrent LVLP production to be zero. They are thus comparable to the decay rates determined earlier for larger viruses (>60 nm) by inhibiting the production of new viruses with cyanide, i.e. $<1.2$ $\mathrm{d}^{-1}$ (Heldal \& Bratbak 1991).

In the enclosures where the nitrate concentration was low and the phosphate was in excess when the Emiliania huxleyi blooms culminated (Table 2, Fig. 3), E. huxleyi comprised up to $94 \%$ (Fig. 3a) and up to $97 \%$ (Fig. 3c) of the phytoplankton communities. In both these enclosures we observed an increase in the abundance of free LVLP as the blooms collapsed (Table 2, Fig. 3a, c). These LVLP were similar in size and morphology to the LVLP observed during the 1988 and the 1989 experiments. The experiments were terminated before we observed a decrease in the LVLP abundances and a second phytoplankton bloom (Fig 3).

\section{Blooms where phosphate concentration was low}

In the enclosures where nitrate was in excess and the phosphate concentration was low $\left(<0.8 \mu \mathrm{mol} \mathrm{l} \mathrm{l}^{-1}\right.$; see 'Discussion') (Table 2, Fig. 4), Emiliania huxleyi comprised about $90 \%$ of the phytoplankton communities at the end of the experiments (Fig. $4 \mathrm{a}, \mathrm{c}$ ). In both experiments there was a small increase in LVLP abundance correlated with the onset of the bloom. The E. huxleyi blooms did not collapse in these experi- 


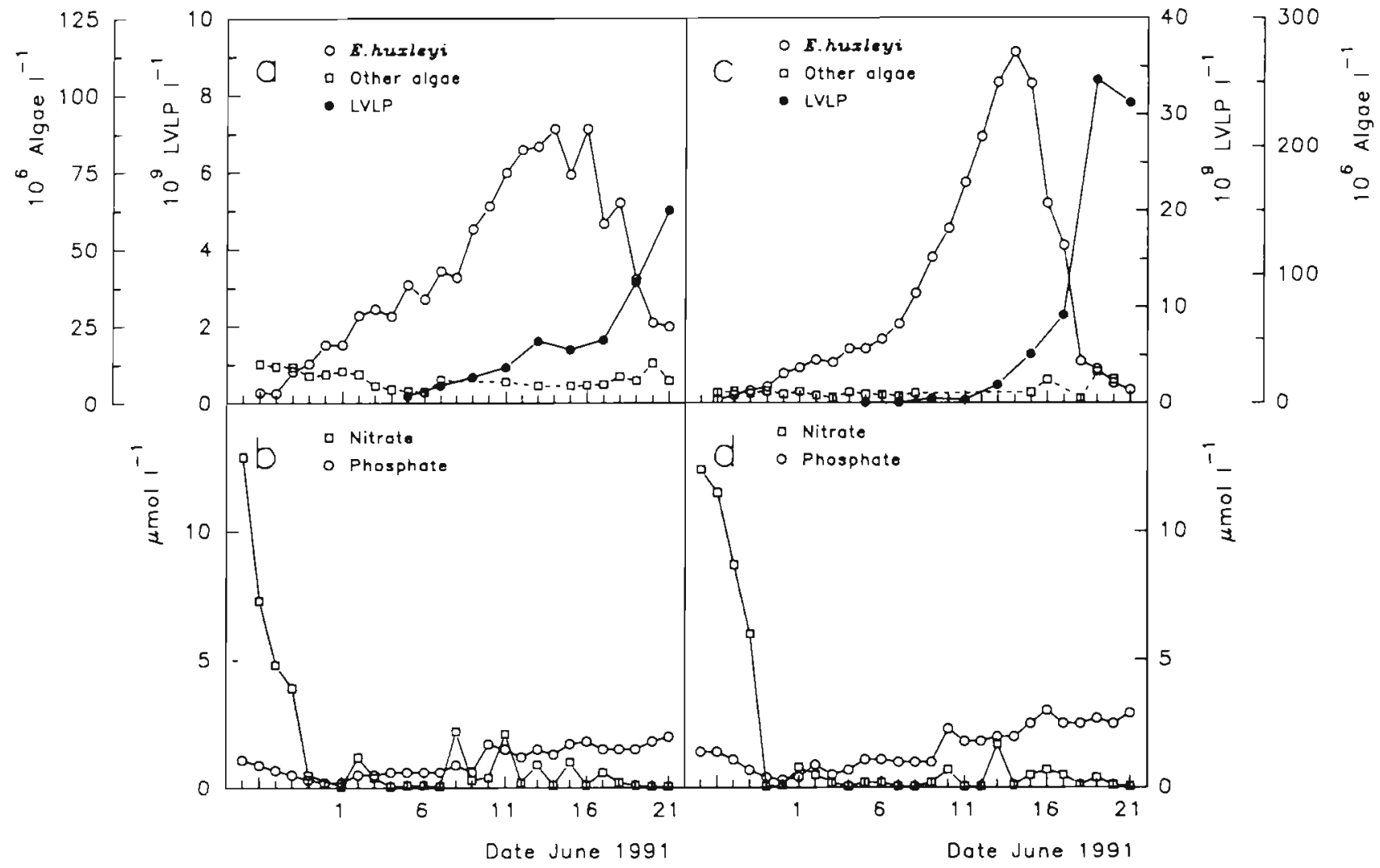

Fig. 3. Emiliania huxleyi. Two parallel mesocosm experiments where the nitrate concentration was low during the E. huxleyi bloom. (a, c) Abundances of E. huxleyi, other algae, and large virus-like particles (LVLP). (b, d) Concentrations of nitrate and phosphate

ments as they did in the experiments conducted simultaneously where the phosphate was in excess (Table 2 , Fig. $3 a, c)$

In the experiments where the concentrations of both nitrate and phosphate were low when the Emiliania huxleyi blooms culminated (Fig. 5), E. huxleyi comprised up to $70 \%$ (Fig. 5a, c) of the phytoplankton communities. In both experiments the E. huxleyi blooms collapsed, but the abundance of free LVLP did not increase significantly (Table 2, Fig. 5a, c) compared to other experiments where a collapse of the bloom was observed (Figs. 1a, c \& 3a,c).

\section{Connections between LVLP and potential host}

The intracellular LVLP found in the thin sections of the cells from the nitrate-deficient enclosure were similar in size and morphology to the free LVLP we enumerated (Fig. 2a, b). In the sample taken on 17 June 1991 about $3 \%$ of the cells contained intracellular LVLP. On this date the Emiliania huxleyi bloom declined and the abundance of free LVLP was increasing
(Fig. 3a, b). Cells containing LVLP in earlier (10 and 14 June) and in later (19 and 21 June) samples made up $<1 \%$ cells in the thin sections.

Clusters of 350 to 700 (mean ca 500) LVLP were occasionally observed in the TEM preparations used for counting of VLP as the Emiliania huxleyi blooms collapsed. The LVLP clusters often surrounded single cells or they appeared to have been squeezed out of the cells (Fig. 2C). These cells were presumably at the point of lysis and had burst as they hit the grid during centrifugation. The LVLP in the clusters were similar in size and morphology to the free LVLP we enumerated.

\section{DISCUSSION}

\section{Connections between L.VI.P and Emiliania huxleyi}

Based on size and morphology the LVLP we enumerated in this study constituted a distinct population (Fig. 2A) although they generally made up less than $5 \%$ of the total count of VLP (data not shown). Several lines of arguments suggests that the LVLP were pro- 


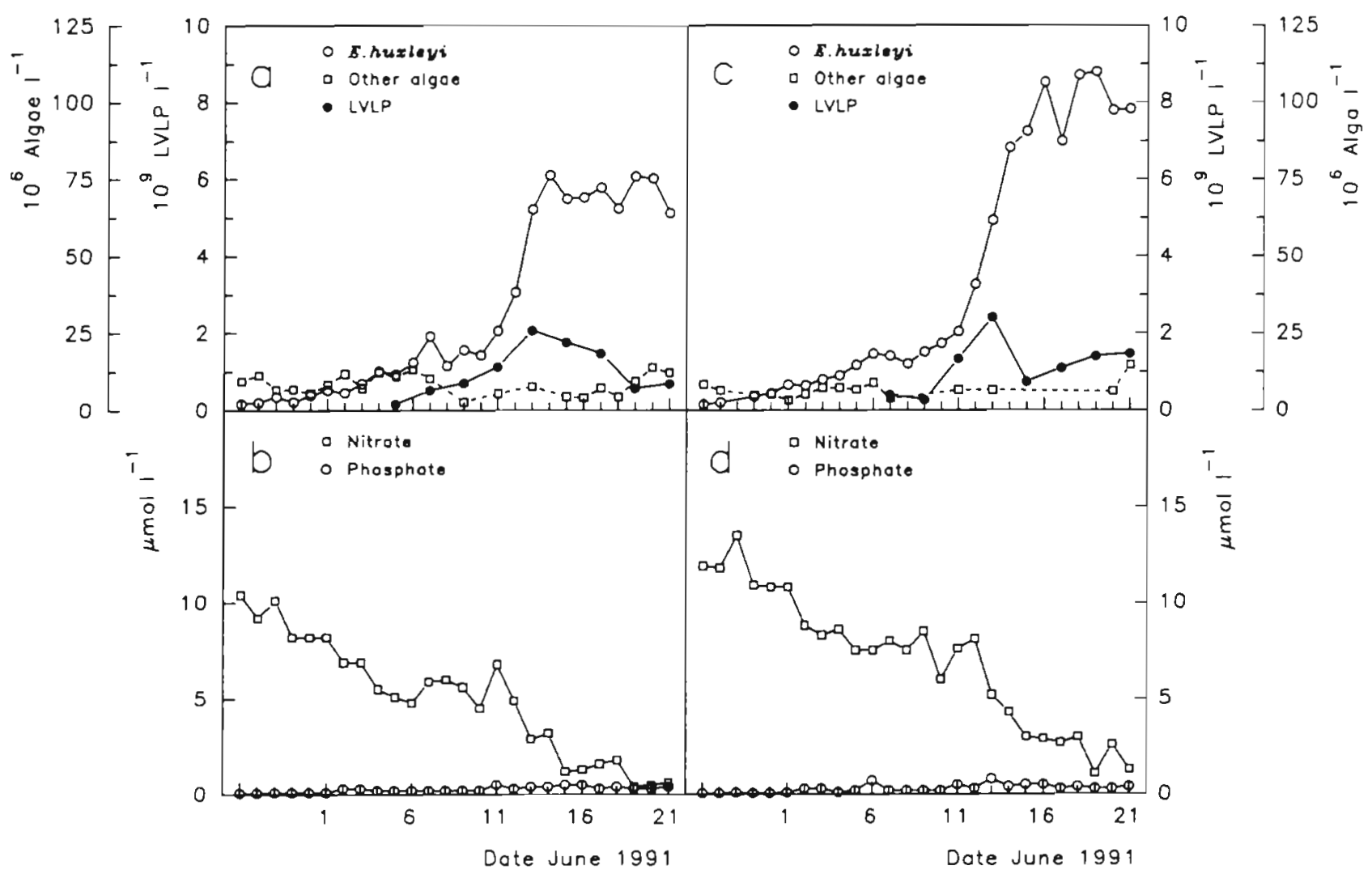

Fig. 4. Emiliania huxleyi. Two parallel mesocosm experiments where the phosphate concentration was low during the E. huxleyi blooms. $(a, c)$ Abundances of $E$. huxleyi, other algae, and large virus-like particles (LVLP). (b, d) Concentrations of nitrate and phosphate

duced by Emiliania huxleyi. The dynamics of the E. huxleyi population and the LVLP population shown in Figs. 1 and 3 are consistent with the idea that this alga suffers from viral infection, lyse and decrease in abundance and cause the number of free LVLP to increase. The LVLP found intracellularly by thin sectioning were similar in size and morphology to the VLP previously found in E. huxleyi cells (Manton \& Leadbeater 1974). The cells that contained intracellular LVLP (Fig, 2B), and the cells that released LVLP (Fig. 2C) were otherwise not different from most cells in these preparations. This suggests that E. huxleyi was the origin of the LVLP since this alga made up $>90 \%$ of the phytoplankton community in these samples. Furthermore, it is very unlikely that any other species could have produced high numbers of LVLP. Even a total collapse of other algae, which made up $<1$ to $6 \%$ of the phytoplankton community in some experiments, cannot account for the high numbers of LVLP observed, unless unreasonably high burst sizes or growth rates are assumed.

Many algae produce viruses that are similar in size and morphology to the LVLP we found associated with Emiliania huxleyi (Dodds 1979, Van Etten et al. 1991).
We argued above that $E$. huxleyi was the origin of the LVLP when the concentrations of these particles were high. Nonetheless, other algae may have produced viruses and contributed to the low LVLP concentrations found when the phytoplankton communities were not dominated by $E$. huxleyi. It is also possible that both $E$. huxleyi and other algae in the enclosures were producing viruses that we did not recognize as distinct populations. Hence, other viruses may have played a role in our experiments that we could not resolve.

Intracellular LVLP were found in about $3 \%$ of the Emiliania huxleyi cells when the bloom collapsed (Fig. 2B). This number is in agreement with earlier studies where in general only 1 to $5 \%$ of the cells in a virus-infected aigal population contained VLP (Van Etten et al. 1991). However, the percentage of LVLP containing cells may have been seriously underestimated. The fact that LVLP-containing cells lysed during centrifugation (Fig. 2c) suggests these cells are very delicate and thus that many cells with LVLP may have lysed during concentration, dehydration and embedding for thin sectioning. Cells with few LVLP are difficult to detect and may therefore have escaped our attention. 


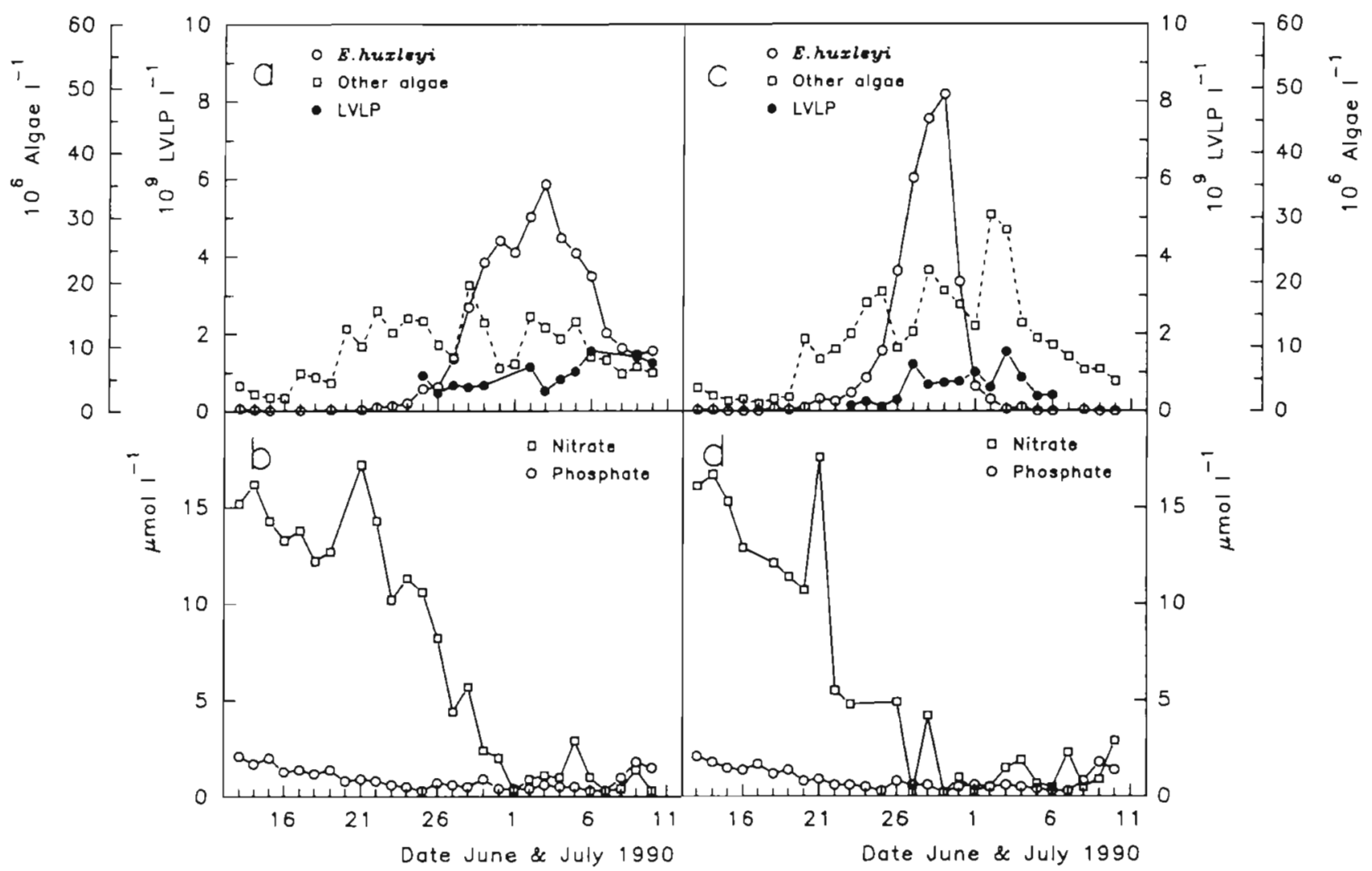

Fig. 5. Emiliania huxleyi. Two parallel mesocosm experiments where the concentrations of both nitrate and phosphate was low during the E. huxleyi blooms. (a, c) Abundances of E. huxleyi, other algae, and large virus-like particles (LVLP). (b, d) Concentrations of nitrate and phosphate

LVLP may not be present in every section of a cell if the LVLP were unevenly distributed intracellularly. The fraction of the lytic cycle in which viral particles may be visible intracellularly varies considerably. The Chlorella-like alga NC64A infected with the virus PBCV -1 has a lytic cycle of 3 to $4 h$, whereas the first mature viruses are present intracellularly 30 to $50 \mathrm{~min}$ prior to spontaneous lysis, i.e. in the last 10 to $30 \%$ of the lytic cycle (Van Etten et al. 1983, 1991). The virus infecting Micromonas pusilla has an eclipse period of $3 \mathrm{~h}$ and a latent period of 7 to $14 \mathrm{~h}$ for individual cells (Waters \& Chan 1982). Viral particles may thus be visible intracellularly in $M$. pusilla in the last 60 to $80 \%$ of the lytic cycle. Considering the fraction of the lytic cycle in which viral particles may be visible intracellularly and the possibility that we have underestimated the percentage of LVLP containing cells, we conclude that the fractions of the E. huxleyi populations that were involved in virus production may have been considerably higher than the $3 \%$ we found to contain LVLP (cf. Proctor \& Fuhrman 1990).

Based on the above discussion we conclude that the LVLP we enumerated were viruses and that Emiliania huxleyi was the host of these viruses.

\section{Mortality of Emiliania huxleyi}

The quantitative importance of viral lysis may be assessed by comparing the number of host cells killed by viral lysis and the total mortality of these cells (Table $3)$. The number of host cells killed by viral lysis $\left(H_{\mathrm{k}}\right.$ cells $\mathrm{l}^{-1}$ ) may be estimated from the number of viruses produced $\left(V_{\mathrm{p}}\right.$, virus $\left.1^{-1}\right)$ and the burst size $(B$, virus cell $^{-1}$ ) i.e. the number of viruses released per lysed cell:

$$
H_{\mathrm{k}}=V_{\mathrm{p}} / B
$$

The number of viruses produced $\left(V_{p}\right.$, virus $\left.1^{-1}\right)$ in the enclosures during the time $\Delta t$ is given by the observed increase in virus concentration $\left(\Delta V\right.$, virus $\left.l^{-1}\right)$, the loss of viruses due to decay $(k V \Delta t)$ and the loss of viruses due to dilution $(D V \Delta t)$ :

$$
V_{p}=\Delta V+k V \Delta t+D V \Delta t
$$

w here $k=$ the rate of viral decay $\left(\mathrm{d}^{-1}\right) ; D=$ dilution rate $\left(\mathrm{d}^{-1}\right)$ in the enclosures (Table 1$)$; and $V=$ mean virus concentration (virus $\mathrm{l}^{-1}$ ) during $\Delta t$. Assuming no growth of Emiliania huxleyi, the net total mortality of 
Table 3. Viral mortality of Emiliania huxleyi estimated for periods where a decrease in the abundance of this alga coincided with an increase in the abundance of large viral-like particles (LVLP). The estimates were made for 2 different viral decay rates ( $k$ )

\begin{tabular}{|c|c|c|c|c|}
\hline \multirow[t]{2}{*}{ Year } & \multirow{2}{*}{$\begin{array}{c}\text { Results } \\
\text { Fig. }\end{array}$} & \multirow[t]{2}{*}{ Date } & \multicolumn{2}{|c|}{ Viral induced mortality as fraction of total net mortality } \\
\hline & & & $k=0 \mathrm{~d}^{-1}$ & $k=0.4 \mathrm{~d}^{-1}$ \\
\hline 1988 & $1 \mathrm{a}$ & $7-8$ Jul & 2.6 & 3.9 \\
\hline 1989 & $1 \mathrm{c}$ & 15-16 Jun & 1.6 & 2.1 \\
\hline \multirow{5}{*}{1991} & $3 a$ & $18^{a}-19$ Jun & 0.13 & 0.36 \\
\hline & $3 a$ & $19-20^{\text {d }}$ Jun & 0.24 & 0.50 \\
\hline & $3 c$ & $14-15$ Jun & \multicolumn{2}{|c|}{ Net algal growth ${ }^{b}$} \\
\hline & $3 \mathrm{c}$ & 15-17 Jun & 0.12 & 0.25 \\
\hline & $3 c$ & 17-19 Jun & 0.71 & 1.1 \\
\hline \multirow[t]{3}{*}{1990} & $5 a$ & $3-4 \mathrm{Jul}$ & 0.42 & 0.68 \\
\hline & $5 a$ & $4-5 \mathrm{JuI}$ & \multicolumn{2}{|c|}{ Net algal growth } \\
\hline & $5 a$ & $5-6 \mathrm{Jul}$ & \multicolumn{2}{|c|}{ Net algal growth } \\
\hline
\end{tabular}

the E. huxleyi population $\left(A_{\mathrm{m}}\right.$, cells $\mathrm{l}^{-1}$ ) during the time $\Delta t$ may be estimated as:

$$
A_{\mathrm{m}}=\Delta A-D A \Delta t
$$

where $\triangle A=$ observed decrease in E. huxleyi abundance $\left(\right.$ cells $I^{-1}$ ); DA $\Delta t=$ loss of $E$. huxleyi cells due to dilution; $D=$ dilution rate $\left(\mathrm{d}^{-1}\right)$ in the enclosures (Table 1); and $A=$ mean $E$. huxleyi concentration (cells $\mathrm{l}^{-1}$ ) during $\Delta t$.

Using Eqs. 1 \& 2 we estimated the viral-induced mortality of Emiliania huxleyi ( $H_{k}$, Eq. 1 ) in those cases where a decrease in the abundance of this alga coincided with an increase in the abundance of LVLP (Figs. 2A, C, 3a, C \& 5a). The burst size $(B)$ was assumed to be 500 as indicated by the number of LVLP surrounding lysed cells (Fig. 2C). The viral decay rate (k) was assumed to be $0.4 \mathrm{~d}^{-1}$ as estimated from the decrease in LVLP abundance (see 'Results'). To obtain a second and more conservative estimate of viral induced mortality we also assumed the viral decay rate to be zero. The concentration of Emiliania huxleyi in the water pumped into the enclosures during the experiments $\left(<1.5 \times 10^{6}\right.$ cells $\left.1^{-1}\right)$ was always too low to have any significant effect on the estimated dilution of E. huxleyi population in the enclosures $(D A \Delta t)$. Considering the low host population it is reasonable to assume that the concentration of LVLP in the inflowing water also was too low to have any significant effect on the estimated dilution of the LVLP population in the enclosures $(D V \Delta t)$. The viral induced mortality of $E$. huxleyi $\left(H_{\mathrm{k}}\right)$ is reported in Table 3 as a fraction of the total net mortality of the E. huxleyi population $\left(A_{m}\right)$ which we estimated using Eq. 3

The decrease in abundance of Emiliania huxleyi was in 3 cases due to dilution and not mortality (Table 3 j. The viral-induced mortality of $E$. huxleyi was in some cases estimated to be higher than the total net mortal- ity (Table 3), even when assuming the viral decay rate to be zero. The total mortality of E. huxleyi was in these cases presumably underestimated due to simultaneous growth, as the growth rate of E. huxleyi in the calculations was assumed to be zero. This view is supported by the fact that the highest estimates of viral mortality (1.6 to 3.9 ; Table 3 ) were obtained in cases where some fraction of the $E$. huxleyi population may still have been growing as the blooms had just culminated (Fig. 1a, c). The estimates of viral mortality from the 1991 experiment (Fig. 3, Table 3) are not prone to this error as they are based on data from periods when the E. huxleyi populations had been declining for several days, indicating that few cells were growing. A higher burst size is another possible explanation, but a 2.6 - to 3.9-fold increase in this parameter seems unlikely. Assuming a viral decay rate of $0.4 \mathrm{~d}^{-1}$ to be a reasonable average, we conclude from the data shown in Table 3 that viral-induced mortality of Emiliania huxleyi accounted for 25 to $100 \%$ of net mortality of this alga. The most straight-forward interpretation of our results is that the viruses caused the blooms to collapse, however, it is possible that the production of viruses occurred coincidently with the collapse of the bloom.

The residual mortality of Emiliania huxleyi may be due to nutrient limitation, grazing by metazoa or protozoa, or possibly by smaller viruses that we did not recognize as a distinct group. Metazoa larger than $25 \mu \mathrm{m}$ were removed in the 1988 experiment and can therefore not account for the mortality in this case. Severe nutrient limitation due to competition from other algae may be a possible explanation for the residual net mortality of Emiliania huxleyi in the 1989 and 1990 experiments (Figs. 1c \& 5), but not in the 1988 and 1991 experiments (Figs. 1a \& 3) where the densities of other 
algae presumably were too low. Nutrient competition may possibly also explain the difference in the fates of the E. huxleyi populations in the experiments where both the phosphate concentration and the abundance of algal viruses were low. In the 1990 experiments, where the densities of other algae were relatively high, the E. huxleyi blooms collapsed (Fig. 5), whereas in the 1991 experiments, where the densities of other algae were low, we observed no collapse of the E. huxleyi blooms within the experimental period (Fig. 4).

\section{Effects of nutrient availability on virus production}

The phosphate concentrations in our experiments were slightly overestimated due to leakage of phosphate from cells during storage of the chloroformpreserved nutrient samples. This was tested during an experiment conducted on 3, 5 and 6 June 1991, where fresh samples had a phosphate concentration of $<0.05$ $\mu \mathrm{mol} \mathrm{l^{-1 }}$ (T. F. Thingstad pers, comm.). After chloroform preservation and storage the concentration had increased to 0.2 to $0.3 \mu \mathrm{mol} \mathrm{l}^{-1}$ (Fig. $4 \mathrm{~b}$ ). The overestimation of the phosphate concentration may to some extent depend on cell abundance and it may thus be more severe in samples where the cell abundance was higher than in the test samples. The overestimation will however not be proportional to the cell abundance as the phosphorus cell quota must have decreased as the blooms progressed in the enclosures designed to become phosphate depleted (Figs. 4 \& 5, Table 1). Based on this, we will argue that the phosphate in these enclosures may have been depleted during the entire experimental period in 1991 (Fig. 4) and from about 25 June and on in the 1990 experiments (Fig. 5) when we measured values $<0.8 \mu \mathrm{mol}^{-1}$.

There was a notable difference in the development of the algal-virus populations in the enclosures where the phosphate concentration was low and presumably depleted, as compared to the enclosures where phosphate was in excess (Table 2). It is not obvious why lack of phosphate seemed to inhibit development of viruses in Emiliania huxleyi, while lack of nitrate appears to be inconsequential. One hypothesis may be that production of viruses is more sensitive to phosphorus limitation than to nitrogen limitation when compared to the production of cellular material since viruses have a higher nucleic acid-to-protein ratio (i.e. $\mathrm{P} / \mathrm{N}$ ratio) than cellular material.

\section{Nature of the host-virus interaction}

We do not know whether virus production depended on infection or on induction of viruses carried by the
Emiliania huxleyi cells. The rate of proliferation of lytic viruses depends on the host cell density and these viruses may therefore play their most important role during blooms when the host cell density is relatively high. The initial rapid increase in viral concentration in the enclosures was observed at an algal concentration between $2 \times 10^{7}$ and $2 \times 10^{8}$ cells $1^{-1}$. In water samples taken $6 \mathrm{~d}$ apart at the end of the E. huxleyi bloom in Norwegian coastal waters in May 1990, we found that the number of algal viruses increased from $3.5 \times 10^{8}$ to $1.4 \times 10^{9} \mathrm{l}^{-1}$ as the number of E. huxleyi cells decreased from $1.3 \times 10^{7}$ to $7 \times 10^{6} 1^{-1}$. Thus, the data do not indicate a fixed host threshold concentration for proliferation of viruses. In addition, it is difficult to see how a lytic virus could persist in the environment during the unproductive part of the year when the host is not present at any significant density, particularly when the estimated decay rate of these viruses 0.1 to $\left.0.8 \mathrm{~d}^{-1}\right)$ is considered. One possibility may however be that the virus has some physical refuges like attachment to particles, low temperature or darkness that protects it from degradation and slows down the decay. It is also possible that a minor subpopulation is more stable than the majority of the LVLP population.

A temperate virus carried by a lysogenic host population can only cause mass mortality of its host by being induced en masse as lysogenic cells are immune to the virus they carry. The rate of proliferation of temperate viruses in a lysogenic host cell population thus depends on the occurrence of spontaneous induction and inducing factors in the environment and not on the host cell density as such. However, to date, no direct evidence for temperate viruses has been reported for any alga (Van Etten et al. 1991).

A third possible mode of interaction between virus and algae is that temperate viruses by mutation may be a source of lytic forms (Lillehaug et al. 1991). The probability for a lytic mutation to arise is related to the number (not necessarily the density) of host cells involved, while the proliferation of this mutant is related to the concentration of host cells. This mechanism may explain how the virus persists in the environment when the host concentration is low and why it proliferates when the host cell concentration is high.

\section{Viral ecology}

Viruses and VLP have been found in many different phytoplankton forms (Dodds 1979, Van Etten et al. 1991). The case for Emiliania huxleyi and virus described here may therefore be just one example of the ecological role of viruses in phytoplankton dynamics. Viruses may accordingly participate in regulation of phytoplankton community composition and diversity, 
and they may provide an answer to Hutchinsons classical paradox (Hutchinson 1961): how is it possible for a number of phytoplankton species, all competing for the same limiting nutrient, to coexist in the sea? The species-specific control of biomass production exercised by viruses may in this context be termed 'side-in' control, as a counterpart to 'top-down' (grazing) and 'bottom-up' (nutrient supply) control (McQueen et al. 1986).

Acknowledgements. We thank Dr B. R. Heimdal for samples from the Norwegian coast, T F. Gulbrandsen and J. LundRassmussen for technical assistance, and Prof. Ian Dundas for discussions and for critically reading the manuscript. The electron microscopy was done at the Laboratory for Electron Microscopy. This work was supported by the Norwegian Research Council for Science and Humanities, the Norwegian Fisheries Research Council and Hejes Foundation.

\section{LITERATURE CITED}

Ackleson, S., Balch, W. M. Holligan, P. M. (1988). White waters of the Gulf of Maine. Oceanography 1: 18-22.

Berge, G. (1962). Discoloration of the sea due to Coccolithus huxleyi 'bloom' Sarsia 6: 27-40

Berger, W. H. (1976). Biogenous deep sea sediments: production preservation and interpretation. In: Riley, J. P., Chester, R. (eds.) Chemical oceanography, Vol. 5. Academic Press, New York. p. 265-388

Børsheim, Y., Bratbak, G., Heldal, H. (1990). Enumeration and biomass estimation of planktonic bacteria and viruses by transmission electron microscopy. Appl. environ. Microbiol. 56: 352-366

Bratbak, G., Heldal, M., Norland, S., Thingstad, T. F. (1990). Viruses as partners in spring bloom microbial trophodynamics. Appl. environ. Microbiol. 56: 1400-1405

Charlson, R. J., Lovelock, J. E., Andreae, M. O., Warren S. G. (1987). Oceanic phytoplankton, atmospheric sulphur, cloud albedo and climate. Nature 326: 655-661

Cottrell, M. T., Suttle, C. A. (1991). Wide-spread occurrence and clonal variation in viruses which cause lysis of a cosmopolitan eucaryotic marine phytoplankter, Micromonas pusilla. Mar. Ecol. Prog. Ser. 78: 1-9

Dodds, J. A. (1979). Viruses of marine algae. Experientia 35: $440-442$

Egge, J. K., Aksnes, D. L. (1992). Silicate as regulating nutrient in phytoplankton competition. Mar. Ecol. Prog. Ser. 83: $281-289$

Heldal, M., Bratbak, G. (1991). Production and decay of viruses in marine waters. Mar. Ecol. Prog. Ser. 72: 205-212

Holligan, P. M., Viollier, M., Harbour, D. S., Camus, P, Champagne-Philippe, M. (1983). Satellite and ship studies of coccolithophore production along a continental shelf edge. Nature 304: 339-342

Honjo, S. (1976). Coccoliths: production, transportation and sedimentation. Mar. Micropaleontol. 1: 65-79

Hutchinson, G. E. (1961). The paradox of the plankton. Am. Nat. 95: $137-45$
Johnson, P. W., Sieburth, J. McN. (1982). In situ morphology and occurrence of eucaryotic phototrophs of bacterial size in the picoplankton of estuarine and oceanic waters. J. Phycol. 18: 318-327

Lillehaug, D. Lindqvist, B. H., Birkeland, N. K. (1991). Characterization of ØLC3, a Lactococcus lactis subsp. cremoris temperate bacteriophage with cohesive singlestranded DNA ends. Appl. environ. Microbiol. 57: 3206-3211

Manton, I., Leadbeater, B. S. C. (1974). Fine-structural observations on six species of Chrysochromulina from wild Danish marine nanoplankton, including a description of $C$. campanulifera sp. nov. and a preliminary summary of the nanoplankton as a whole. Biol. Skr. Dan. Vid. Selsk. 20: $1-26$

Mayer, J. A., Taylor, F. J. R. (1979). A virus which lyses the marine nanoflagellate Micromonas pusilla. Nature 281: 299-301

McQueen, D. J., Post, J. R., Mills, E. L. (1986). Trophic relationships in freshwater pelagic ecosystems. Can. J. Fish. Aquat. Sci. 43: 1571-1581

Pienaar, R. N. (1976). Virus-like particles in three species of phytoplankton from San Juan Island, Washington. Phycologia 15: 185-190

Proctor, L. M., Fuhrman, J. A. (1990). Viral mortality of marine bacteria and cyanobacteria. Nature 343: 60-62

Proctor, L. M., Fuhrman, J. A. (1991). Roles of viral infection in organic particle flux. Mar. Ecol. Prog. Ser. 69: 133-142

Sieburth, J. McN., Johnson, P. W., Hargraves, P. E. (1988). Ultrastructure and ecology of Aureococcus anophagefferens gen. et sp. nov. (Chrysophyceae): the dominant picoplankter during a bloom in Narragansett Bay, Rhode Island, summer 1985. J. Phycol. 24: 416-425

Strickland, J. D. H., Parsons, T. R. (1972). A practical handbook of seawater analysis, 2nd edn. Bull. Fish Res. Bd Can. 167: $1-310$

Suttle, C. A., Chan, A. M., Cottrell, M. T. (1990). Infection of phytoplankton by viruses and reduction of primary productivity. Nature 347: 467-469

Suttle, C. A., Chan, A. M., Cottrell, M. T. (1991). Use of ultrafiltration to isolate viruses from seawater which are pathogens of marine phytoplankton. Appl. Environ. Microbiol. 57: $721-726$

Utermohl, H. (1931). Neue Wege in der quantitativen Erfassung des Planktons. (Mit besonderer Berücksichtigung des Ultraplanktons.) Verh. Int. Verein. Theor. Anegw. Limnol. 5: $567-596$

Van Etten, J. L., Burbank, D. E., Xia, Y., Meints, R. H. (1983). Growth cycle of a virus, PBCV-1, that infects Chlorellalike algae. Virology 126: 117-125

Van Etten, J. L., Lane, L. C., Meints, R. H. (1991). Viruses and viruslike particles of eucaryotic algae. Microbiol. Rev. 55 : 586-620

Waters, R. E., Chan, A. T (1982). Micromonas pusilla virus The virus growth cycle and associated physiological events within the host cells; host range mutation. J. gen Virol. 63: 199-206

Westbroek, P., Young, J. R., Linchooten, K. J. (1989). Coccolith production (biomineralization) in the marine algae Emiliania huxleyi. J. Protozool. 36: 368-373

Manuscript first received: October 5, 1992

Revised version accepted: December 21, 1992 